\title{
Primary production and size-fractionated structure of the Black Sea phytoplankton in the winter- spring period
}

\author{
D. K. Krupatkina, Z. Z. Finenko, A. A. Shalapyonok \\ Institute of Biology of the Southern Seas, Ukrainian SSR Academy of Sciences, Nakhimov pr. 2, 335000 Sevastopol, USSR
}

\begin{abstract}
Basic photosynthetic characteristics determining the shift in phytoplankton species and size composition from coccolithophores and dinoflagellates to diatoms were investigated. The study revealed a slight seasonal decrease in the light utilization efficiency $\left(\alpha_{\text {chl }}\right)$ from 0.078 to $0.056 \mathrm{mg} C$ ( $\left.\mathrm{mg} \mathrm{chl} \mathrm{a}^{-1}\right) \mathrm{h}^{-1}\left(\mathrm{~W} \mathrm{~m}^{-2}\right)$ from winter to early spring, as well as a small increase in the photosynthesis light saturation ( $I_{k} ; 29.4$ and $45.5 \mathrm{~W} \mathrm{~m}^{-2}$, respectively) and in the diurnal assimilatory number [DAN; 19.6 and $24.0 \mathrm{mg} \mathrm{C}(\mathrm{mg} \mathrm{chl} \mathrm{a})^{-1} \mathrm{~d}^{-1}$, respectively]. At the same time, respiration $(R)$ fell drastically: in winter, when phytoplankton was dominated by dinoflagellates and coccolithophores, $R$ was $29 \%$ of maximum production $\left(P_{\max }\right)$, while in spring, with diatoms dominating, $R$ was $2.5 \%$ of $P_{\max }$. Chlorophyll a concentration also showed a drastic increase from 0.73 to $2.15 \mathrm{mg} \mathrm{m}^{-3}$ in the surface layer and from 20 to between 100 and $150 \mathrm{mg} \mathrm{m}^{-2}$ on an areal basis. These data suggest that the nearly 2 -fold growth of primary production from winter to spring (275.2 \pm 163.5 and $581.4 \pm 232.4 \mathrm{mg} \mathrm{C} \mathrm{m}^{-2} \mathrm{~d}^{-1}$, respectively) is accounted for by larger phytoplankton biomass and lower respiration. These changes were mainly brought about by an increase in diatoms: the increase of both production and chlorophyll a from winter to spring features an ever greater diatom contribution, reaching $>50 \%$ in spring. A close relationship is suggested between the increase in primary production and the changes in the structure of seawater from winter to spring.
\end{abstract}

\section{INTRODUCTION}

Winter and early spring see an upsurge of diatom development in the Black Sea. These large-size colonial forms replace smaller unicellular ones - coccolithophores and dinoflagellates - predominant in the late autumn and early winter phytoplankton (Belogorskaya \& Kondratyeva 1965). This study investigated the basic phytosynthetic characteristics that determine the shift in the phytoplankton species and size structure from coccolithophores and dinoflagellates to diatoms.

\section{MATERIALS AND METHODS}

The study was carried out during the 25th cruise of the RV 'Professor Vodyanitsky' (December 1987 to January 1988) and the 49th cruise of the RV 'Mikhail Lomonosov' (March 1988) in the Black Sea.

Primary production was measured using simulation in situ (Harrison et al. 1985). Total primary production and chlorophyll a were measured in the pelagic zone in the western part of the Black Sea at 25 stations in winter ( 1 December to 20 January) and 26 stations in early spring (6 to $26 \mathrm{March}$ ) (Fig. 1A, B). Primary production of various size-fractionated phytoplankton assemblages was measured in December 1987, and January and March 1988. Samples for primary production estimates were obtained using a glass flow bathometer from 8 depths of the euphotic zone selected to correspond to irradiations equal to $100,63,34,12,5,2$, 1 and $0.5 \%$ of surface solar irradiance $\left(I_{0}, \mathrm{~W} \mathrm{~m}^{-2}\right.$ PAR). The decrease of light with depth was measured with a submersible quantum sensor. This device was designed at the Marine Hydrophysical Institute of the Ukrainian Academy of Sciences for measuring the light absorption coefficient in the blue part of the spectrum: $\lambda_{\text {eff. }}=480 \mathrm{~nm}$ (Weinermann \& Neuimin 1978). The sensor has a cosine collector, a colour filter and a selenium element. When operated, it is suspended on a 3 -core cable. The signals are checked on board at $5 \mathrm{~m}$ intervals during descent and ascent, using a digital 

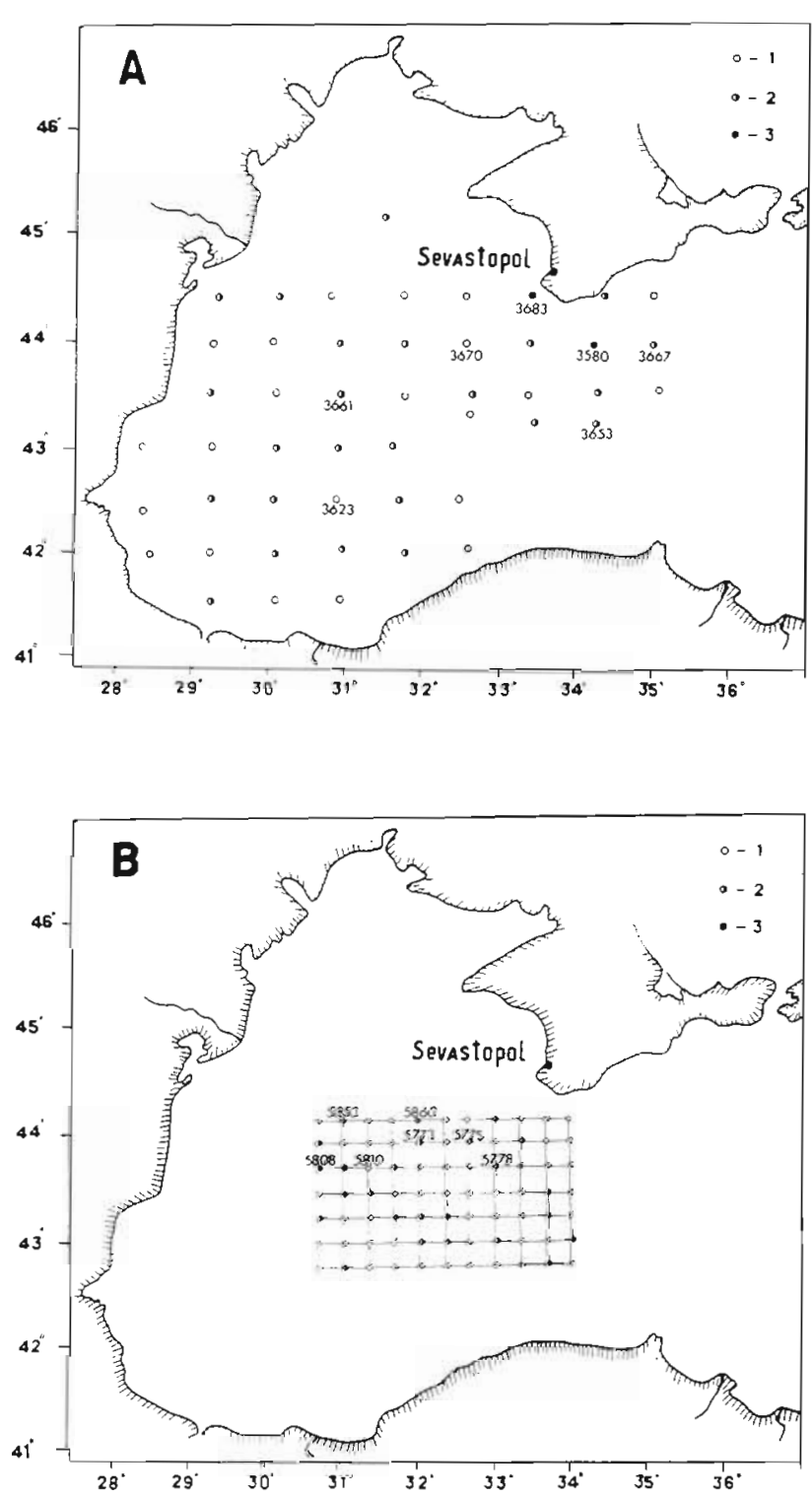

Fig. 1. Location of field stations in the Black Sea (A) in winter and $(B)$ in early spring. 1 : chlorophyll $a ; 2$ : primary production; 3: primary production in different size-fractionated groups of phytoplankton microvoltmeter. Measurements from surface to between 40 and $50 \mathrm{~m}$ depth took under $5 \mathrm{~min}$ which minimized radiation variability due to clouds. Measurements were made once a day with the sun high $\left(h_{0} \geqslant 45^{\circ}\right)$. These data were used to calculate the quotient of weakening of the solar energy flow $(K)$ and the depths $(Z)$ to which the above-mentioned percentages of light penetrated

Water samples from each depth were incubated in 0.251 polycarbonate bottles (in duplicate), inoculated with purified $\mathrm{NaH}^{14} \mathrm{CO}_{3}\left(20 \mu \mathrm{Ci}\right.$ or $\left.74 \times 10^{4} \mathrm{~Bq}\right)$, and placed into the appropriate incubator compartment with flowing seawater. Each of the 8 incubator compartments was irradiated using neutral light filters to reduce light to the level corresponding to each depth. The incubator was exposed on deck for half the daytime, usually from between 6:00 and 7:00 h to between $12: 00$ and 13:00 h. Incubation temperature was the same as that of the sea surface.

Irradiation was continuously measured with a U-116 luxmeter. Then, total irradiation for the exposure time was calculated in klux. The latter was transformed to $\mathrm{W} \mathrm{m}^{-2}$, using the relationship of Kleshnin (1954): $1 \mathrm{klux}$ $=5.8 \mathrm{~W} \mathrm{~m}^{-2}$. Subsequently, the light intensity for each incubator section was calculated as $100,63,34,12,5,2$, 1 , and $0.5 \%$ of $I_{0}$. Using graphs of production vs irradiation, maximum production $\left(P_{\max }\right)$ under light saturation $\left(I_{k}\right)$ as well as minimum production $\left(P_{\min }\right)$ were calculated. $P_{\text {min }}$ in spring was found at about the depth to which 0.5 to $1 \%$ of $I_{0}$ penetrated, i.e. at about 35 to $40 \mathrm{~m}$, and in winter at the depth of 2 to $5 \%$ of $I_{0}$, i.e. 25 $\mathrm{m}$. These data demonstrate considerable deepening of the euphotic zone from winter to spring. $P_{\text {max }}$ in spring was found at depths with 100 to $63 \%$ of $I_{0}$, i.e. about 0 to $3 \mathrm{~m}$, but in winter only at that with $100 \%$ of $I_{0}$, that is on the very surface. These data show no inhibition of photosynthesis in winter, and negligible inhibition in spring in the pelagic zone.

Maximum diurnal assimilation number [DAN $\mathrm{Dax}_{\operatorname{mith}}$ $k_{1} \operatorname{mg} \mathrm{C}(\mathrm{mg} \mathrm{chl} a)^{-1} \mathrm{~d}^{-1}$ ] was calculated by dividing $P_{\max }\left(\mathrm{mg} \mathrm{m}^{-3} \mathrm{~d}^{-1}\right)$ by chlorophyll concentration $\left(\mathrm{mg} \mathrm{m}^{-3}\right)$

Table 1. Mean values of primary production (PP, $\left.\mathrm{mg} \mathrm{C} \mathrm{m}^{-2} \mathrm{~d}^{-1}\right)$, chlorophyll $a$ in the surface layer $(0 \mathrm{~m})\left(\mathrm{chl} \mathrm{a}, \mathrm{mg} \mathrm{m}^{-3}\right)$, diurnal assimilation number [DAN, mg C $\left.(\mathrm{mg} \mathrm{chl} \mathrm{a})^{-1} \mathrm{~d}^{-1}\right]$, light utllization effectiveness $\left[\alpha_{\mathrm{ch}}, \mathrm{mg} \mathrm{C}(\mathrm{mg} \mathrm{chl} \mathrm{a)})^{-1} \mathrm{~h}^{-1}\left(\mathrm{~W} \mathrm{~m}^{-2}\right)^{-1}\right]$ and photosynthesis light saturation $\left(I_{k}, \mathrm{~W} \mathrm{~m}^{-2}\right)$

\begin{tabular}{|c|c|c|c|c|c|c|}
\hline \multirow[t]{2}{*}{ Parameter } & \multicolumn{3}{|c|}{ Winter } & \multicolumn{3}{|c|}{ Spring } \\
\hline & $\begin{array}{c}\text { No. of } \\
\text { observations }\end{array}$ & $\bar{x}$ & SD & $\begin{array}{c}\text { No. of } \\
\text { observations }\end{array}$ & $\overline{\mathrm{x}}$ & $\mathrm{SD}$ \\
\hline PP & 22 & 275.2 & 163.5 & 22 & 581.4 & 232.4 \\
\hline ChI a & 50 & 0.74 & 0.04 & 65 & 2.15 & 0.70 \\
\hline$D A N_{\max }$ & 22 & 19.0 & 8.8 & 22 & 24.1 & 7.5 \\
\hline$\alpha_{\text {chl }}$ & 20 & 0.078 & 0.02 & 20 & 0.056 & 0.03 \\
\hline$I_{k}$ & 20 & 29.37 & 15.07 & 20 & 45.46 & 20.71 \\
\hline
\end{tabular}


at the maximum production depth. A 'day' is assumed equal to the daylight period from sunrise until senset, which at the latitude of the Black Sea is about $10 \mathrm{~h}$ in winter and $12 \mathrm{~h}$ in early spring. Light utilization efficiency $\left[\alpha_{c h l i} m g C(m g c h l a)^{-1} h^{-1}\left(W m^{-2}\right)^{-1}\right.$ ] was calculated by dividing assimilation number $[A N$; $m g$ C ( $m g$ chl a $)^{-1} \mathrm{~h}^{-1}$ ) by $I_{k}\left(\mathrm{~W} \mathrm{~m}^{-2}\right)$.

Samples for measurement of primary production and chlorophyll a were filtered through $0.4 \mu \mathrm{m}$ filters (Synpor). The phytoplankton was size-fractionated, using a set of 2 filters and a nylon sieve (Krupatkina et al. 1987). The filter pore-size varied from $20 \mu \mathrm{m}$ in the upper nylon sieve to 2.5 and $0.45 \mu \mathrm{m}$ in the middle and lower filters (Synpor and Sartorius, respectively). Filtration was initiated under vacuum (ca 0.1 to $0.2 \mathrm{~atm}$ ) and continued under the hydrostatic pressure caused by a ca $70 \mathrm{~cm}$ height difference. Thus the phytoplankton was conventionally divided into small $(0.4$ to $2.5 \mu \mathrm{m})$, medium-size $(2.5$ to $20 \mu \mathrm{m})$ and large $(>20 \mu \mathrm{m})$ fractionated groups.

Radioactivity was measured using a 1215 RackBeta (LKB Wallac Co., Finland) counter. Respiration was measured by the Winkler method as the decrease in oxygen concentration between zero-time samples and samples incubated for 10 to $12 \mathrm{~h}$ in the dark. Incubation was carried out at in situ temperature, using calibrated
Fig. 2. Dependence of the maximum assimilation number $\left(\mathrm{DAN}_{\text {max }}\right.$ with $I_{k}$ ) on primary production. (A) Winter, (B) spring.

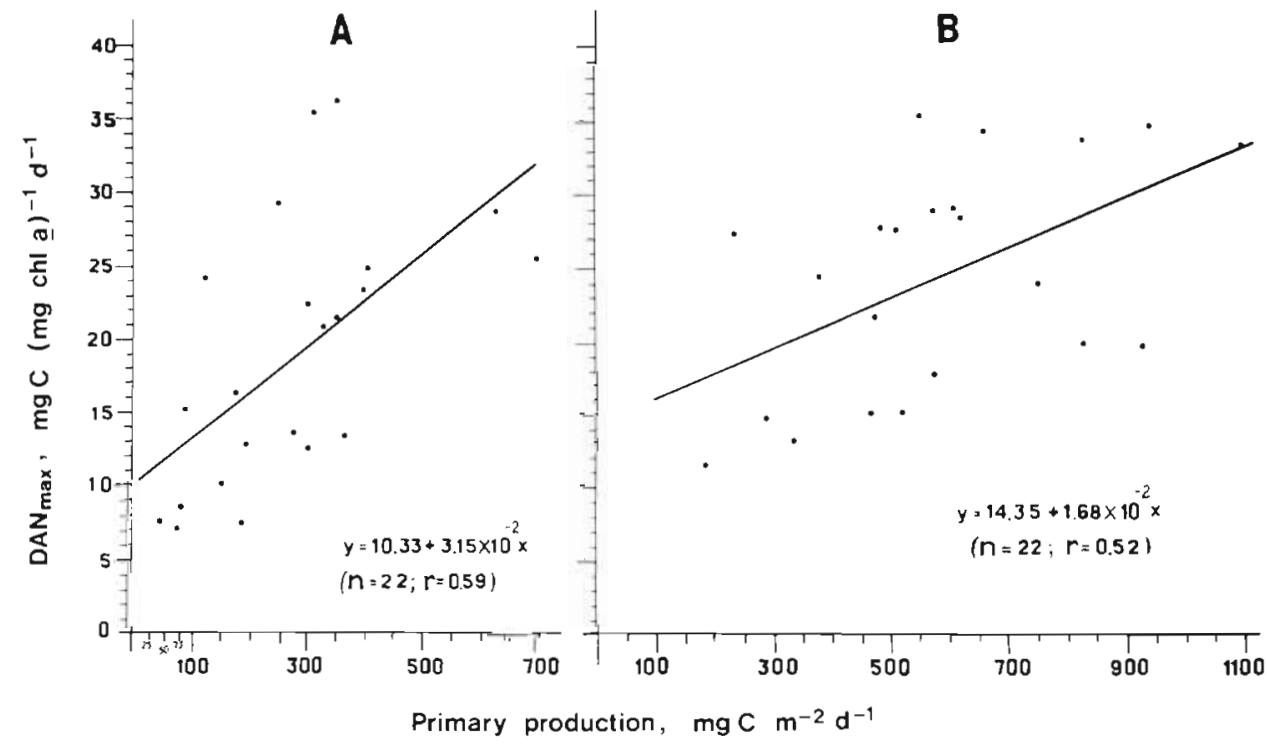

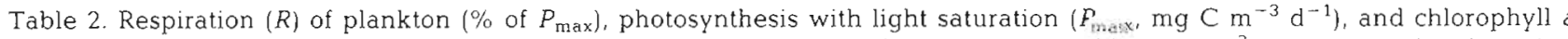
concentration in the pelagic surface layer of the Black Sea and Sevastopol Harbour $(0 \mathrm{~m})$ ( chl $a_{1} \mathrm{mg} \mathrm{m}^{-3}$ ) in winter and early spring

\begin{tabular}{|c|c|c|c|c|c|}
\hline \multicolumn{3}{|c|}{ Winter } & \multicolumn{3}{|c|}{ Spring } \\
\hline $\mathrm{R}(\%)$ & $P_{\text {max }}$ & Chl a & $\mathrm{R}(\%)$ & $P_{\text {mad }}$ & Chl a \\
\hline \multicolumn{6}{|c|}{ Pelagic waters } \\
\hline $\begin{array}{l}29.21 \pm 3.55 \\
\mathrm{n}=10\end{array}$ & $14.06 \pm 7.5$ & $\begin{array}{l}0.74 \pm 0.04 \\
\mathrm{n}=50\end{array}$ & $\begin{aligned} 2.50 & \pm 1.44 \\
\mathrm{n} & =4\end{aligned}$ & $51.8 \pm 16.1$ & $\begin{array}{l}2.15 \pm 0.70 \\
n=65\end{array}$ \\
\hline \multicolumn{3}{|c|}{$\begin{array}{l}\text { Dominating species: } \\
\text { Coccolithophores and } \\
\text { dinoflagellates }\end{array}$} & \multicolumn{2}{|c|}{ Dominating species: } & \\
\hline \multicolumn{3}{|c|}{$\begin{array}{l}\text { Pontosphaera huxleyi } \\
\text { Exuviaella compressa } \\
\text { Exuviaella cordata } \\
\text { Peridinium sp. } \\
\text { Gymnodinium sp. }\end{array}$} & \multicolumn{3}{|c|}{$\begin{array}{l}\text { Rhizosolenia calcar-avis } \\
\text { Rhizosolenia alata } \\
\text { Nitzschia ceriata } \\
\text { Nitzschia delicatissima }\end{array}$} \\
\hline \multicolumn{6}{|c|}{ Sevastopol Harbour } \\
\hline $\begin{array}{l}3.95 \pm 1.7 \\
\mathrm{n}=8\end{array}$ & $1201 \pm 430.3$ & $31.5 \pm 12.9$ & $\begin{array}{c}6.4 \pm 4.6 \\
\mathrm{n}=4\end{array}$ & $1171.5 \pm 240.3$ & $33.9 \pm 8.7$ \\
\hline \multicolumn{3}{|c|}{$\begin{array}{l}\text { Dominating species: } \\
\text { Blooming Skeletonema costatum }\end{array}$} & \multicolumn{3}{|c|}{$\begin{array}{l}\text { Dominating species: } \\
\text { Blooming Chaetoceros curvisetus }\end{array}$} \\
\hline
\end{tabular}


$500 \mathrm{ml}$ bottles. Respiration was converted to per cent of increase in oxygen concentration in a light bottle $\left(P_{\max }\right.$ with $k$ ). Chlorophyll $a$ and phaeophytin a concentrations were determined fluorimetrically (Yentsch \& Menzel 1963, Lorenzen 1967, Yunev \& Berseneva 1986).

\section{RESULTS}

\section{Total phytoplankton primary production and photosynthetic characteristics}

Primary productivity in winter typically amounted to $<500 \mathrm{mg} \mathrm{C} \mathrm{m}^{-2} \mathrm{~d}^{-1}$, and in spring $<1000 \mathrm{mg} \mathrm{C} \mathrm{m}^{-2} \mathrm{~d}^{-1}$ (Fig. 2A, B). Average production in winter was 275.2 and in spring $581.4 \mathrm{mg} \mathrm{C} \mathrm{m}{ }^{-2} \mathrm{~d}^{-1}$ (Table 1), representing a 2 -fold increase from winter to spring. Chlorophyll a concentration at the surface $(0 \mathrm{~m})$ increased from 0.74 in winter to $2.15 \mathrm{mg} \mathrm{m}^{-3}$ in spring, i.e. 3 -fold. Hence the spring increase of production was rather due to higher phytoplankton biomass than to changes in photosynthetic parameters. In support of this assumption, one may point to a small seasonal decrease in the light utilization efficiency $\left(\alpha_{\text {chl }}\right)$ from 0.078 to $0.056 \mathrm{mg} \mathrm{C}$ $(\mathrm{mg} \mathrm{chl} \mathrm{a})^{-1}$. There was but a small change in the diurnal assimilation number (DAN) from winter to spring [19.0 and $24.1 \mathrm{mg} \mathrm{C}(\mathrm{mg} \mathrm{chl} \mathrm{a})^{-1}$, respectively]. Coupled with this, a drastic decrease in respiration (expressed relative to production) was observed. In winter, when small unicellular forms (coccolithophores and dinoflagellates) dominated the phytoplankton, respiration accounted for $29 \%$ of $P_{\max }$. In spring, with species and size structure changes in favour of large-sized colonial forms (diatoms), respiration decreased to $2.5 \%$ of $\mathrm{P}_{\max }$ (Table 2).

Noteworthy is the low respiration ( 4 to $6 \%$ of $P_{\max }$ ) in blooming diatoms in Sevastopol Harbour in both winter and spring (Table 3).

The vertical distribution of chlorophyll a varied from
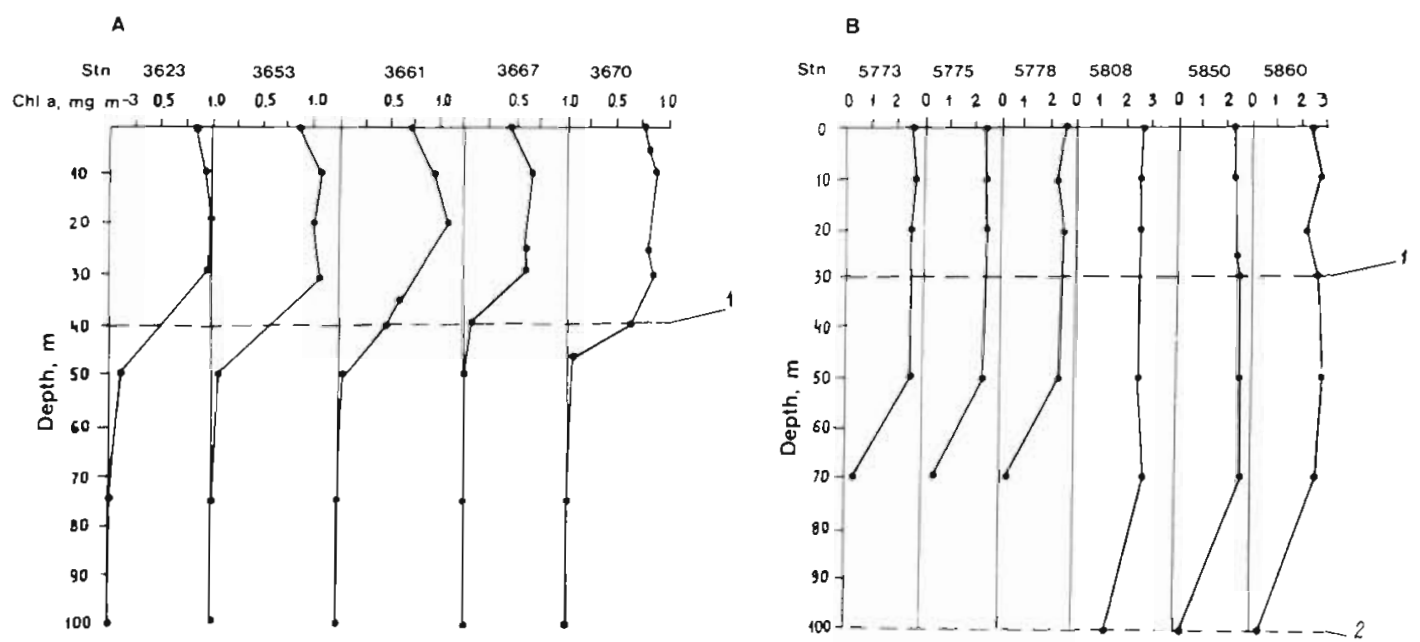

Fig. 3. Vertical distribution of chlorophyll a (chl $a_{1}$ mg $\mathrm{m}^{-3}$ ). (A) Winter. 1: Extent of euphotic zone and mixed layer (B) Spring. 1. Euphotic zone; 2: mixed layer

Table 3. Primary production (PP, \% of overall value), chlorophyll a $\left(\mathrm{mg} \mathrm{m}^{-3}\right)$ and assimilation number $\left[\mathrm{AN}_{\max }, \mathrm{mg} \mathrm{C} \mathrm{mg}_{\mathrm{m}} \mathrm{chl} a\right)^{-1}$ $\mathrm{h}^{-1}$ ] of 3 size-fractioned communities of phytoplankton; small, medium and large $(>0.4 ;>2.5$ and $>20 \mu \mathrm{m}$, respectively), in winter and early spring 1987-1988, Black Sea. The small size fraction was mainly represented by coccolithophores and dinoflagellates (Pontosphaera huxleyi, Exuviaella compressa, E. cordata, Peridinium sp., Gymnodinium sp.), the large one by colonial diatoms (Rhizosolenıa calcar-avis, $R$. alata, Nitzschia ceriata, $N$. delicatissima)

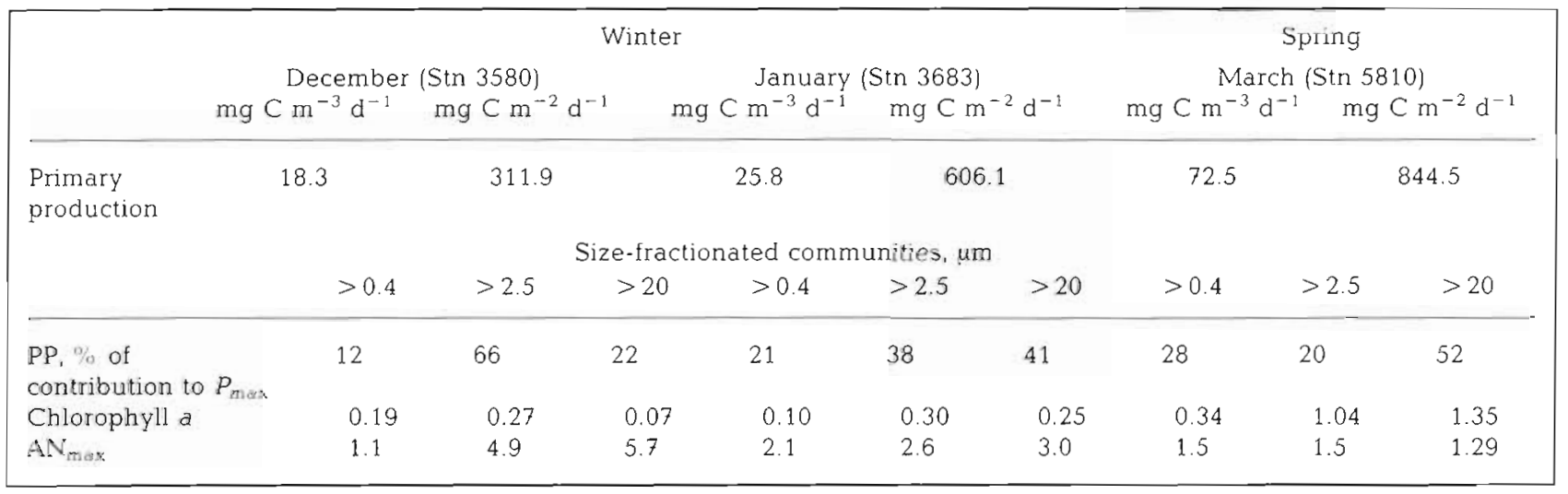



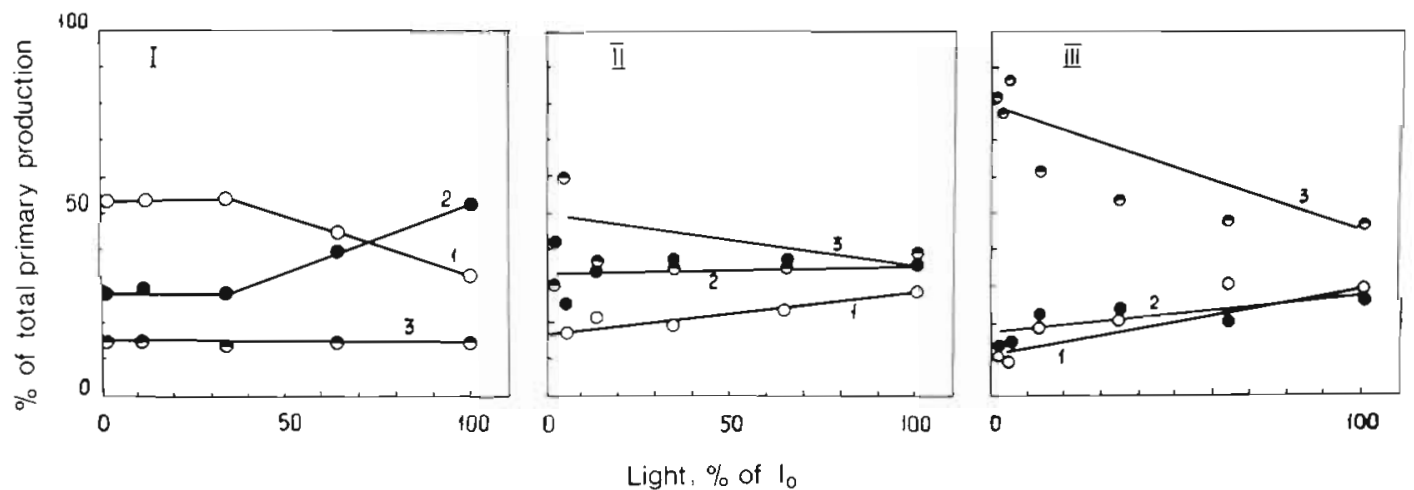

Fig. 4. Variation of the contribution of different size-fractionated communities to primary production under different light levels (1 to $100 \%$ of surface irradiance). (I and II) Winter: (I: Stn 3580, 21 Dec 1987; II: Stn 3683, 17 Jan 1988); (III) early spring (Stn 5810 , 17 Mar 1988). 1. small $(0.4$ to $2.5 \mu \mathrm{m})$; 2 : medium $(2.5$ to $20 \mu \mathrm{m})$; 3 : large $(>20 \mu \mathrm{m})$ size-fractioned groups

winter to spring (Fig. 3): in winter the concentration was uniform down to $30 \mathrm{~m}$ depth and in spring to 50 and even $70 \mathrm{~m}$. The surface concentration $(0 \mathrm{~m})$ increased from $0.74 \mathrm{mg} \mathrm{m}^{-3}$ in winter to $2.14 \mathrm{mg} \mathrm{m}^{-3}$ in spring (Table 2). Hence the average seasonal concentration of chlorophyll a per $\mathrm{m}^{2}$ fluctuated from 20 to between 100 and $150 \mathrm{mg} \mathrm{m}^{-2}$.

\section{Diatom primary production and photosynthetic characteristics}

The increase of primary production from winter to spring was partly due to an increasing diatom contribution (Rhizosolenia calcaravis, Rhizosolenia alata, Nitzschia ceriata, Nitzschia delicatissima) to the overall

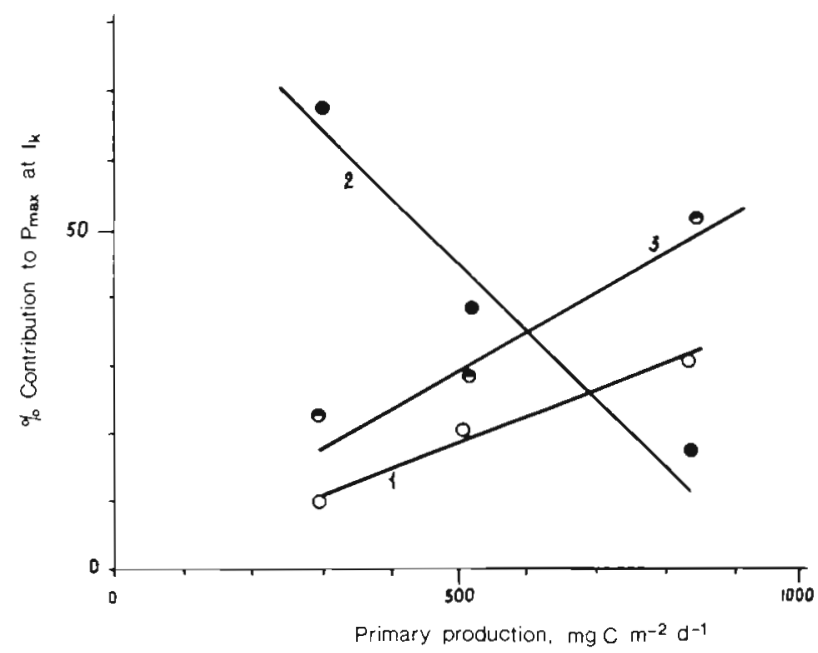

Fig. 5. Variation in the contribution of various size-fractionated communities to primary production (percentage of overall value of $P_{\max }$ at $I_{k}$ ) in the course of the primary production increase from winter to spring. 1 : Small $(0.4$ to $2.5 \mu \mathrm{m}) ; 2$ : medium ( 2.5 to $20 \mu \mathrm{m})$; 3: large size-fractionated communities $(>20 \mu \mathrm{m}$ ) (unicellular and colonial diatoms) production value (Table 3, Figs. $4 \& 5$ ). At the station where primary production was highest (Stn 5810), their contribution was found to be greatest $(>50 \%)$. However, the increase was possibly due to the fact that these diatom species have the highest $P_{\max }$ to $P_{\operatorname{mnn}}$ ratio (Fig. $6 \mathrm{~A}, \mathrm{~B})$. During the spring period of maximum primary production, this ratio became virtually the same for

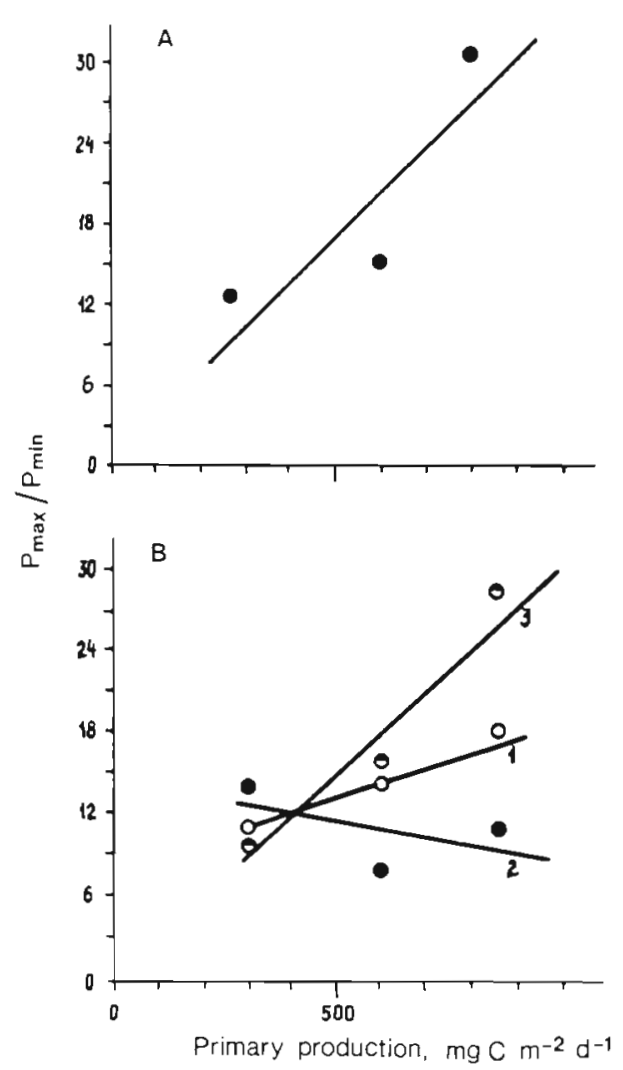

Fig. 6. Variation of the $\mathrm{P}_{\max } / \mathrm{P}_{\mathrm{min}}$ ratio of $(\mathrm{A})$ the phytoplankton and (B) its various size-fractionated communities during the primary production increase in winter and early spring (notation as in Fig. 5) 


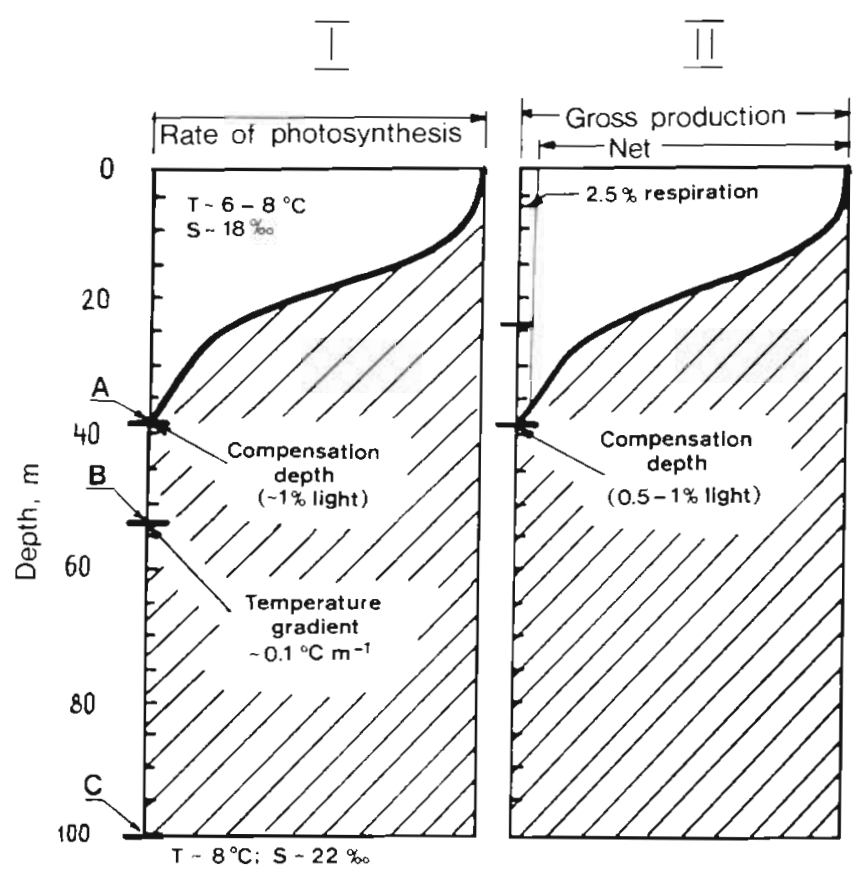

diatoms and overall phytoplankton production, and this can be considered a convincing argument in favour of a major contribution by diatoms. There is also a tendency for the contribution by diatoms to overall chlorophyll a to be maximum from winter to early spring. Likewise, the station at which the contribution of diatoms was greatest (Stn 5810) was that where chlorophyll was highest. $A N_{\max }$ for diatoms decreased (Table 3) from 5.7 in winter to $1.29 \mathrm{mg} \mathrm{C}(\mathrm{mg} \mathrm{chl} \mathrm{a})^{-1} \mathrm{~h}^{-1}$ in spring.

\section{DISCUSSION}

The described increase of primary production can be compared with seasonal changes in the seawater structure. In early spring, seawater temperatures (Fig. 7, 1) are still very low $\left(6\right.$ to $\left.8^{\circ} \mathrm{C}\right)$. With the virtually unchanged temperature, and irradiation only 1.5 times higher than in winter, there comes about an extremely important change in the seawater stratification. Markedly stratified waters divided by a seasonal thermocline into upper and lower layers due to storms and surface chilling-off merge into a quasi-homogeneous (in temperature) 'mixed layer'. Since the temperature gradient at the lower bounding of this mixed layer (ca $50 \mathrm{~m}$ ) is only ca $0.1^{\circ} \mathrm{C} \mathrm{m}^{-1}$, this layer extends downwards as far as the main pycnocline (ca $100 \mathrm{~m}$ ). The euphotic zone $\left(100 \%\right.$ to $1 \%$ of $I_{0}$ ) extends to ca $40 \mathrm{~m}$ depth, i.e. is 2.5 times shallower than the mixed layer. The lower boundary of the euphotic zone is marked by the compensating depth ( $1 \%$ of light) where the photosynthetic rate is generally assumed to be counterbalanced by respiration.

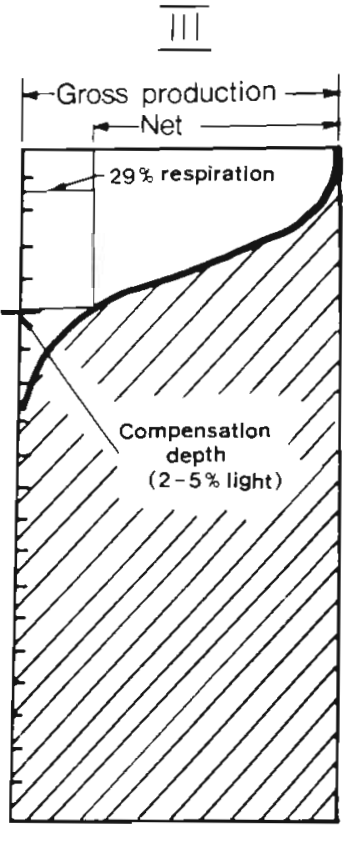

Fig. 7. Some features of hydrologic structure and primary production in the Black Sea in winter and early spring (schematic). (I) Surface layer structure $(0$ to $100 \mathrm{~m}$ ) in terms of light penetration and primary production. A: mean depth of euphotic zone; $B$ : mean depth of mixed layer; $C$ : mean depth of main pycnocline. (II) Net and gross primary production with diatoms dominating (in spring). (III) Net and gross primary production with coccolithophores and dinoflagellates dominating (in winter)

The $100 \mathrm{~m}$ deep mixed layer having formed, lower waters periodically upwell bringing so-called 'new' nutrients to the lower strata of the euphotic zone and somewhat below ( 30 to $50 \mathrm{~m}$ depth). The high content of these elements (e.g. 30 to $40 \mathrm{mg} \mathrm{P}-\mathrm{PO}_{4} \mathrm{~m}^{-3}$, Dobrzhanskaja 1967; $111.9 \pm 25.7 \mathrm{mg} \mathrm{N}-\mathrm{NO}_{3} \mathrm{~m}^{-3}, \mathrm{n}=65$ Kirikova pers. comm, - the same early spring cruise 1988 ) is only advantageous for those algae that, drifting downwards, are able to adapt to dim light or even total darkness over rather long periods of time, about 20 to 30 h or probably more (Nalewajko et al. 1981, Smith \& Barker 1985, Nalewajko \& Valtolina 1986). Hence they should be characterised by extremely low respiratory losses.

Diatoms seem to possess such qualities. Thus, with diatoms dominating the spring phytoplankton, respiration was low and so net production roughly equalled gross production (Fig. 7. II). On the other hand, in winter, when coccolithophores and dinoflagellates prevailed, relative respiration was about an order of magnitude higher and, consequently, net production. was less than gross production (Fig. 7. III). Admittedly the oxygen technique used measures overall plankton respiration. However, as demonstrated by Kuparinen (1987), in early spring this overall respiration during the diatom bloom may be regarded as that of diatoms alone. The present investigation supports this assumption through the finding that the diatom contribution to the high spring chlorophyll concentrations $(2.15 \mathrm{mg}$ $\left.\mathrm{m}^{-3}\right)$ is the largest $(50 \%)$. As was shown by Bell \& Kuparinen (1984), in early spring diatom respiration is very low and therefore gross and net production are practically equal. The same follows from our recent 
Table 4. Light utilization effectiveness in marine phytoplankton $\left[\alpha \mathrm{chl}, \mathrm{mgC}(\mathrm{mg} \mathrm{chl} a)^{-1} \mathrm{~h}^{-1}\left(\mathrm{~W} \mathrm{~m}^{-2}\right)^{-1}\right]$ of the Arctic, middle latitudes and Black Sea

\begin{tabular}{|lcl|}
\hline Area of investigation & $\alpha$ chl & \multicolumn{1}{c|}{ Source } \\
\hline $\begin{array}{l}\text { Middle latitudes } \\
\text { (Nova Scotia, littoral) }\end{array}$ & 0.21 & $\begin{array}{l}\text { Platt \& Jassby } \\
(1976)\end{array}$ \\
Arctic zone & $0.049 \pm 0.007$ & $\begin{array}{l}\text { Platt et al. } \\
(1982)\end{array}$ \\
$\begin{array}{l}\text { East Canada } \\
\text { (Arctic zone) } \\
\text { Middle latitudes } \\
\text { (Canadian littoral) }\end{array}$ & $0.044-0.056$ & $\begin{array}{l}\text { Harrison et al. } \\
\text { Middle latitudes, } \\
\begin{array}{l}\text { Black Sea (winter, } \\
\text { spring, pelagic waters) }\end{array}\end{array}$ \\
\hline
\end{tabular}

review paper (Krupatkina 1990, Table 3), which further shows that, when diatoms dominant, phytoplankton respiration is low (Table 2).

With the large mixed layer, water circulation will be relatively slow, which may confine diatoms to a long stay in low light or even in total darkness. Their long stay in weak irradiation may be somehow related to the decrease of $\alpha_{\mathrm{chl}}$ in early spring. In our opinion, it coincides with the decrease in $\alpha_{\mathrm{chl}}$ in middle latitudes at the same time of year (Platt \& Jassby 1976). On the whole, we obtained $\alpha_{\mathrm{chl}}$ data for the overall phytoplankton (Table 4) similar to those cited for Arctic and middle latitudes.

\section{LITERATURE CITED}

Bell, T R., Kuparinen, J. (1984). Assessing phytoplankton and bacterioplankton production during early spring in Lake Erken, Sweden. Appl. environ. Microbiol. 48: 1221-1230

Belogorskaja, E. V., Kondratyeva, T. M. (1965). Phytoplankton distribution in the Black Sea. In: Vodjanitski, $V$ A. (ed.) Planktonic investigations in the Black Sea and Azov Sea. Naukova Dumka, Kiev, p. 36-69

Dobrzhanskaja, M. A. (1967). Phosphate distribution at various depths in the Black Sea. In: Vodjanitsk, V. A. (ed.)

This article was presented by G. G. Polikarpov, Sevastopol, USSR
Water dynamics and problems of the Black Sea hydrochemistry. Naukova Dumka, Kiev, p. 104-126

Harrison, W. I., Platt, T., Lewis, M. R. (1985). The utility of light-saturation models for estimating marine primary productivity in the field: a comparison with conventional 'simulated' in situ methods. Can. J. Fish. Aquat. Sci. 42 (5): $864-872$

Kleshnin, A. F. (1954). Rasteniye i svet. Teoriya i svetokultura rasteniy. Izd. AN SSSR, Moskva

Krupatkina, D. K. (1990). Estimates of primary production in oligotrophic waters and metabolism of picoplankton: a review. Mar. Microb. Food Webs 4 (1): 87-101

Krupatkina, D. K., Lopukhin, A. S., Kamenir, J. G. (1987). Sizefractionated distribution of the Tropical Atlantic phytoplankton and its impact on the estimates of primary production and chlorophyll ' $a$ ' in waters of different trophicity. Okeanologia 27 (3): 470-473

Kuparinen, J. (1987). Production and respiration of overall plankton and ultraplankton communities at the entrance to the Gulf of Finland in the Baltic Sea. Mar. Biol. 93, 591-607

Lorenzen, C. V. (1967). Determination of chlorophyll and phaeopigments: spectrophotometric equations. Limnologica $12: 343-346$

Nalewajko, C., Lee, K., Shear, H. (1981). Phosphorus kinetics in Lake Superior: light intensity and phosphate uptake in algae. Can. J. Fish. Aquat. Sci. 38: 224-232

Nalewajko, C., Voltolina, D. (1986). Effects of environmental variables on growth rates and physiological characteristics of Lake Superior phytoplankton. Can. J. Fish. Aquat. Sci. 43: $1163-1170$

Platt, T., Jassby, A. D. (1976). The relationship between photosynthesis and light natural assemblages of coastal marine phytoplankton. J. Phycol. 12 (4): 421-430

Platt, T., Harrison, W G., Irwin, B., Horne, E. P., Gallegos, C. L. (1982). Photosynthesis and photoadaptation of marine phytoplankton in the Arctic. Deep Sea Res. 29 (10 A): $1159-1170$

Smith, R. C., Barker, K. S. (1985). Spatial and temporal patterns in pigment biomass in Gulf Stream warm-core ring $82 \mathrm{~B}$ and its environs. J. geophys. Res. 90 (5): 8859-8870

Weinermann, B. A., Neuimin, G. G. (1978). Pribor dlya izmereniya podvodnoy obluchonnosty. In: Nelepa, B. A (ed.) Eksperimental 'nyye metody issle-dovaniya okeana. Marine Hydrophysical Institute, Sevastopol', p. 144-151

Yentsch, C. S., Menzel, D. W. (1963). A method for determination of phytoplankton chlorophyll and phaeophytin by fluorescence. Deep Sea Res. 37 (3): 471-483

Yunev, O. A., Berseneva, G. P. (1986). Fluorimetrichesky metod opredeleniya kontsentratsii khlorofila ' $a$ ' $v$ fitoplanktone. Gidrobiol. 2h. 22 (2): 85-95

Manuscript first received: June 28, 1989

Revised version accepted: February 19, 1991 